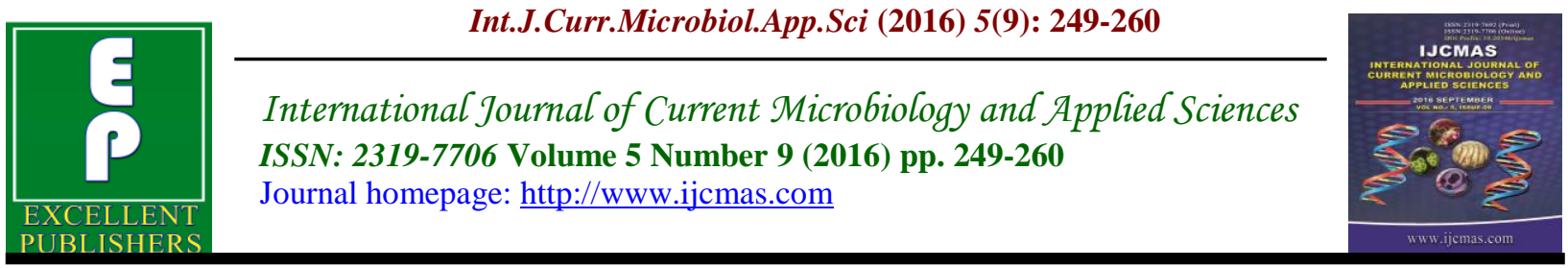

Original Research Article

http://dx.doi.org/10.20546/ijcmas.2016.509.028

\title{
Response of Maize to Skip Irrigation and Some of Growth Regulators and Sunflower Extract
}

\author{
Nabil R. Lahmod ${ }^{1 *}$, Oda H. Eshkandi ${ }^{1}$ and Srra'a. N.M. Al-Eqaili ${ }^{2}$ \\ ${ }^{1}$ Department of Agronomy, College of Agriculture, University of Wasit, Wasit, Iraq \\ ${ }^{2}$ Department of Biology, College of Science, University of Mustansiriya, Baghdad, Iraq \\ *Corresponding author
}

\section{Keywords}

Skip irrigation, sunflower extract, GA3, salicylic, maize

\section{Article Info}

Accepted:

10 June 2016

Available Online:

10 September 2016

\section{A B S T R A C T}

To investigated efficacy of skip irrigation and some of plant growth regulator and sunflower extract on maize yield, a field experiment was conducted on field crop department - college of agriculture / was it university at summer season 2013. RCBD design by split plot arrangement was used to study skip irrigation treatment as main plots, with four treatment of growth regulators as subplots represent GA3 (100 ppm), salicylic acid (200ppm), sunflower extract (5\% w/v) and control treatment (distil water only). Two spread were repeated on shot plant; first was after month from sowing and second before flowering stage. Result showed decline of maize yield by skip irrigation treatment compared with traditional irrigation by $23 \%$ percentage. While improved growth components yield of maize. Sunflower extract, GA3 and salicylic acid were increased yield by 19, 15 and $13 \%$ percentage alternatively compared with control. Interaction between irrigation treatment and growth regulator was not significant. However growth regulator component caused equal increased with both irrigation ways, as well as, sunflower extract applied or GA3 amended from crop ability of drought tolerance in skip irrigation treatment, which not significant different in yield from traditional treatment irrigation and that refer to moderated of effect drought on yield. Yield component appeared that yield was come to increased number of grain and weight of grain bases which represent essential yield component. From this result, can be concluded that ability of saving $50 \%$ percentage from water irrigation and keeping of maize yield through using of skip irrigation with moderated water stress by growth regulator or sunflower extract sprayed on maize.

\section{Introduction}

Water is an element of life for all living organisms and is one of the most important components of agricultural production, based on the amount of water available can be built of agricultural and economic policies for both systems countries dependent on surface irrigation or rain fed. In Iraq, irrigated land represent the greater part of agricultural land that stretches from Mosul city in the North and Basra in the South abut more than 22.11 million hectare, as well as some northern areas which may 
irrigate through wellspring. Due to low water levels of the Tigris and Euphrates rivers because of politics that taken by States of upper Mesopotamia (Turkey, Syria), which made it the quantities needed to meet water requirements of crops are insufficient, and in front of this challenge to water-starved problem many research efforts focused on water sources such as wells and springs and water drainage to fill these needs, however, the use of these practices may have some adverse effects on production and some chemical and physical soil characteristics (Humadi, 2001). Turn specialists in the area of field crops and plant breeding to look for ways to manage through which to minimize the effects of water stress on the plant, such as improving crop varieties characterized by its susceptibility to drought tolerance (Alusi, 2005) or the use of certain chemical compounds as growth regulators, such as GA3,IAA, CK3, and fertilizers or plant extracts, which can give the plant the possibility of water conservation or reduce transpiration or increased water potential of the cells (Levitt, 1980; Garrity' O'Toole, 1994; Rathinasabapathi, 2000 and Blume, 2005). Also, some agricultural operations such as ploughing and depth of agriculture and plant densities may increase the ability of soil to retain water or increase the possibility of root system of getting the right moisture processing plant (Saad et al., 1985; Elmuttalibi, 1990).

One of the strategies followed in rationing water needs and achieve the highest yield from them without losses on water to groundwater is the use of skip irrigation method for furrows or terraces (Elsahookie et al., $2006 \mathrm{a}, \mathrm{b})$, as is pass the irrigation water in one side of furrows and other mutually. This is one of irrigation methods which may increase the efficient use of water and can be applied in the field, in order to reduce the rates of evaporation transpiration of crop, and this probably will provide quantities of irrigation water estimated at almost $50 \%$ from the transpiration of the crop at low moisture content of the root zone with less injury on plant compared with traditional irrigation (Hammoud, 2010) and that it may provide the possibility of introducing other agricultural areas without the need to provide new sources of water. In spite of these measures, but some crops, such as maize may be affected as a result of moisture deficit on the plant, and this influence varies by product and the nature of the soil and planting date, which could reduce economic yield. This effect on plant can be different according to cultivars, soil structure, date of sowing that will be decrease of yield because water stress or heat temperature through flowering stage of maize it may reduce the number of grains in ear maize or weight as a result of failure Fertilization and abortion struggled disorder esteem ovaries and cereals (Zinselmeier, 1995 and Setter et al., 2001). With the worsening problem of water scarcity and droughts have varied procedures followed by the researchers in the reduction of the damage between the increased efficient use of water(WUE)) of crops and introduction of some chemical compounds to increasing the plant resistant to drought (Al-Hussaini, 2013) or the merger between them. Recent studies have refer to the possibility of the use of natural extracts crude for some plants to lessen the effect of water stress on the crop, it was found by Makkar and Becker (1996) that the use of a plant leaf extract like Moringa oleifera $\mathrm{L}$ reduced the effects of drought on the maize crop, it has attributed this effect to the presence of a group of compounds and growth regulators such as zeatin, ascorbates, carotenoids, phenols, some antioxidants and minerals essential, which was also confirmed by both Fuglie 
(1999) and Foidl et al., (2001), this might signal that contain this extract on compound or growth regulators may delay senescence's of leaves and inhibits oxidative molecules in the cell (Al-Hussaini, 2013). Other studies show that low concentrations for some Allelopathy compounds in plant extracts usually have a catalytic effect on plant growth (Cheema, 2012), it has been found by Maqbool (2010) that the low concentrations of sorghum extract was stimulate maize growth and increased productivity. Al-Temimi (2010), Alsaadawi et al., (2011), Lahmod et al., (2014) have reached to the existence of many of the phenolic compounds and Allelopathy in water extract of sunflower as Caffeic acid, Gallic acid, Hydroxy benzoic acid, Pcoumaric acid, ferulic acid and catechol that maybe if used few concentrations may stimulate maize growth or reduce the effects of water stress through reducing transpiration or close some of stomata $(\mathrm{Al}$ Hussaini, 2013) as the presence of some wax compounds may close stomata in the upper leaf (Epistomatous) which reduces water loss process of transpiration and increase the efficient use of water (Abd El-kader, 2006). Other studies, referring to the role of a compound salicylic acid to increase the plant tolerance of drought as a result of doing this acid in the inhibition of ethylene in the plant and the movement of the stomata control, it also has effective converse to abscisic acid (ABA) and has the ability to bind to amino acids and give plant resistance to systemic acquired, it is also salicylic acid as antioxidants that have a role in the link with active oxygen molecules which cause oxidation to enzymes and inhibition of photosynthesis and the senescence's of the plant (Gupta, 2011 and Pessaraki, 2007). The use of more than way as package in order to reduce the impact of drought or improve plant to resistance, may come back positive result the growth and yield of crops.
So the use of skip irrigation with some growth regulators method and plant extracts may provide the amount of irrigation water and reduces the loss of economic yield as result of water stress on the plant, hence has developed this study, the aim of a statement of skip irrigation efficiency and extract residue of sunflower and some growth regulators in the growth and yield of maize.

\section{Materials and Methods}

A field experiment in the agricultural fields carried to the College of Agriculture, University of Wasit include the cultivation of maize in furrow during 20.7.2013. The experiment was conducted by randomized completely block design (RCBD) and arranging as split plots with four replications, represented main plots for skip irrigation and traditional irrigation while growth regulators and sun flower extract in the sub- plots, represent : salicylic acid concentration of $200 \mathrm{ppm}$ (Ismail, 2013), Gibberellin (GA3) concentration 100 ppm (Akter et al., 2014) and the aqueous extract of residue sunflower concentration of $(5 \%$ w/v)(Al-Hussaini, 2013), in addition to the treatment compared to only sprayed with water as control. Has been tilling the soil and preparing for planting in early July of 2013, as it has been tilling the soil by mouldyplough inverter and softening by rotovetor plow and then furrowing by agricultural dicher the distance between furrow and another $90 \mathrm{~cm}$. The high up to $40-50 \mathrm{~cm}$ for furrow. Every four furrows 10 meters long represent experimental unit of irrigation main plots within four secondary treatments for growth regulators are distributed randomly in the four block. Phosphate fertilizers at a rate of $250 \mathrm{~kg} / \mathrm{h}$ as $\mathrm{P} 2 \mathrm{O} 5$ in the third top of furrow and placed in a simple incision and then filled in the soil to cover. The furrows irrigated confidential reproach to the extent of two- 
thirds of furrow high to determine the agriculture line, after five days have been planting maize seeds variety (Diar) in holeat the agriculture line on the eastern side of the furrow and a distance of $20 \mathrm{~cm}$ between hole and other, then gave all confidential field first agriculture irrigation. Has irrigation process by mechanical pump diameter of 3 inch tied with a plastic pipe wheelchair is transferred between the stream of the field when irrigation, as was the calibration of the flow by the time to full furrow to agriculture line in traditional irrigation ((ie up to 800 m3 / hectare for each single irrigation) (Hammoud, 2010)). The experiment was irrigated almost weekly when appear any signs of drought on the soil, as it is irrigated all furrows in traditional irrigation while irrigation from one side of furrow and mutually between one irrigation and the other in skip irrigation treatments. The growth regulators treatments have all been sprayed as foliage applied twice during the growing season by hand 2-liter watering can with a shelter between treatments to avoid the spray transfer to neighbouring treatments. First spray was conducted in the first month after germination, while the second was carried out before the flowering stage, as it was spraying is in the evening times.

\section{Prepare cosmetic spray}

Prepare GA3 solution was obtained tablets material GA3 of commercial shopping concentration of $50 \%$ active ingredient and then dissolving small amounts of ethanol, and then dissolved the tablets with distilled water concentration of $100 \mathrm{ppm}$.

Salicylic acid: Use of powder material salicylic acid and then dissolving the required quantity in a small amount of ethanol and then dissolved in distilled water.

Prepare of sunflower residue extract: attended the aqueous extract of the residue stems, leaves and the heads without seed of the sunflower crop together (Flamy cultivar) thin crushed the residue mechanical. Weighed the required quantity, then add the hot water(90 degrees Celsius) and stir the mixture to cool and then the solution filtered by three layers of cloth to prevent the passage of impurities to the solution (AlHussaini, 2013).

Nitrogenous fertilizer was added at a rate of $300 \mathrm{~kg} / \mathrm{h}$ at feeding near the plant after sowing, first times was applied after the completion of germination and the second applied when the plants in flowering stage, also conducted thinning plants into one plant in each hole after germination is complete in the field to get the optimal plant density of the crop. When arrival crop to Physiological maturity stage was taking measurements required by electing five random plants from each treatment unit, taking into account to stay away from the guard lines, after it has been measuring the height of the plant in the field, was cut five plants elected from the ground level with its yield learned them and put into bags and taken to the store for drying and left to dry under natural atmosphere till reach the stability of the weight. Weigh samples entirely to calculate the biological weight and then separated ears of plants and removed sleeves and then neglected to manually calculate the number of grains in each ear and weight of grain, also calculate the weight of 500 grain of each sample, then calculate economic yield in hectares according to plant density used, and calculate harvest index.

Data were analyzed statistically and mathematical Means were compared according to test last significant difference (L.S.D) at p- value (0.05) in Steel and Torrie (1988). 


\section{Results and Discussion}

\section{Effect of skip irrigation and growth regulators in the high of maize plant}

Plant height represents a growth traits that indicate an increase in dry matter when there is a suitable space for the reception of solar radiation by the leaves (Hammoud.2010). The high was increased due to increased competition between crop plants or weed on the light at high plant intensities. Results in Table 1. Notice that there is a significant effect for irrigation in plant height, the height of the plant in the treatment of skip irrigation fell by $11 \%$ from the traditional irrigation and and this probably is a natural result of the effect of water deficit resulting from the cell elongation and division, and reflected on the elongation of stem internode (Hillel, 1990). This result lack of skip irrigation, and may reduce the elongation of the roots in the early stages of growth (Elsahookie et al., 2006 and Akter et al., 2014). This effect maybe caused a direct effect in is go with what Hammoud (2010) found that plant height reduced when compared skip irrigation with traditional irrigation weekly. Effect of plant growth regulators in spraying plant height of maize, caused sunflower extract treatments and GA3 significant increase in plant height by 7 and $8 \%$ compared with the treatment which has been sprayed with water only while salicylic acid addition treatment did not differ on treatment of significantly comparison. Lahmood (2012) referred that the plant height maybe associated hormonal factors or growth regulators more effect growth than from its association with external factors, and gibberellins which is one of the plant hormones produced naturally within the plant, and cause cell elongation will result to increased plant height (Akter and others.2014), and the presence of some phenolic compounds in the remnants of sunflower may have spurred the growth and elongation of the cells, it was found by Al-Hussaini (2013) that phenolic compounds in sorghum residue extract caused an increase in the dry matter of the green gram plant, as mentioned Maqbool (2010) that the little concentrations of the sorghum extract significantly stimulated maize growth and increased productivity. Interaction was not significant between the growth regulators and irrigation treatments in plant height as growth regulators caused a commensurate increase in both irrigation treatments. It is noted that the improved growth due to spray GA3 and extract of sunflower in skip irrigation transactions made from plant height was not significantly different from the treatment of comparison in the traditional irrigation, and this improvement may be the result of the impact of GA3 in cell elongation and increasing the division, which may stop due to tensile moisture on the plant (Shao et al., 2008 and Rodriguez et al., 2006), also Akter et al., (2014) refer to the outside of the spray GA3 has caused a marked increase in plant height maize exposed to moisture stress in different growth stages, also noted Cheema et al., (2012) that some plant species extracts can improve the viability of the plant in drought tolerance if sprayed on the shoot at certain concentrations, and this is what Al-Hussaini (2013)found in a spray of sorghum extract of the green gram plant exhibition to water stress.

The effect of skip irrigation and plant growth regulators on yield and yield components of maize

\section{Number of grains in ear maize}

Yield consists of several components associated with some of which with other components to affect ultimately increase the dry grain material, and one of those 
components is the grains number of ear maize and the weight of the grain, which is clear from the results they may be significantly affected in the skip irrigation transactions and the addition of growth regulators, the number of grain dropped in ears maize to about $20 \%$ in skip irrigation transactions compared to traditional irrigation (table 2.) this underlines the fact that the irrigation effect on the success or failure of the process of pollination, or embryo growth and that explained by a number of researchers, as the physiological disorder in the plant as a result of some growth factors, such as water lack when flowering change might affect the readiness of pollen to fertilize the ovaries (asynchronization), which reduces the number of grains in ears maize due to fertilization failure (Setter et al., 2001). Also Zinselmeier et al., (1995) found that the increase in water stress in the stages of flowering and pollination increase the abortion grain. The effect of growth regulators and interaction with irrigation did not significantly influence the number of grains, as the cause of skip irrigation significant decrease with added of all the growth regulators.

\section{Weight of 500 grains (g)}

There is no significant effect of irrigation on the grain weight (Table 3) and this is probably due to the low number of grains in ear for the treatment of skip irrigation (Table 2 ), as the yield components normally associated with some of which relationship counterproductive, especially when there is no an increase in the assimilation from sources enough to offset the competition, as the increasing number of ears in the plant, that maybe photosynthesis products distribution on the largest number of ear which reduces the share each ear, as well as increasing the number of grains per ear maybe reduces the amount of photosynthesis products per grain if it is not associated with increased in the amount of photosynthesis products from source, but when there is an increase on photosynthesis products processing, increasing yield may come from increasing the survival of one of the components with the other components fixed or reduced or increase a few percent are not commensurate with the rate of increase in the first component (Elsahookie, 2007). Add sunflower extract caused significant increase in grain weight (154.16 g.) which was not significantly different from the treatment of spraying salicylic acid which amounted to (149.17 g.) while the $(146.04$ g.) reached in the treatment of comparison, which was not significantly different from spraying treatment of GA3 (147.87 g.). The increased grain weight in the spraying treatment of sunflower extract may be due to the presence of certain organic compounds that stimulate the growth (Fuglie, 1999; Foidl, 2001) and these compounds may delay the senesces of leaves and inhibit oxidisers (Al-Hussaini, 2013), which It improves the efficiency of the process of photosynthesis and increases the accumulation of photosynthesis products added in the grain.

The effect of interaction between the growth regulators and irrigation treatment noting that sunflower extract gave an increase in grain weight in the drought treatment (skip irrigation) more than the effect of salicylic acid and GA3 so that these treatments gave the weight of the grain did not differ or may sometimes increase than the grain weight in the traditional irrigation treatment, and this sign of improving plant in case of drought resistance, and this is what refer to it by Cheema and others (2012) that some plant species extracts can improve the viability of the plant in drought tolerance. 


\section{Grains Yield (t / h)}

Table 4 represents the effect of skip irrigation and plant growth regulator in the yield of grains, which represents the final outcome of the vital processes occurring in the plant. Table 4. appeared the effect of skip irrigation treatment on the decline of yield by $23 \%$ compared to traditional irrigation and this is expected result of the lack of irrigation in the number of grain in ear or grain weight (table 2 and 3), which represent the basic yield components. When the moisture shortfall as a result of irrigation lack of effect in the overall physiological processes of the plant, reducing plant growth and reduced in parts of the reproductive also reduced the accumulation of dry matter as a result of the decline process of photosynthesis and the accumulation digestive enzymes and the free radicals ROS and that work on the demolition of protein and an imbalance in the carbohydrate gathered (Kole 2011 and Anjum et al., 2011). Additional that, a plant exposed to drought usually cause liberation ABA hormone, which in turn causes the closure of the stomata, which reduces the entry of $\mathrm{CO} 2$ in the process of photosynthesis (Hirt and Cedrs, 2004). Influenced spray growth regulators process significantly in the yield of grain maize, it has given the treatment sprayed remnants of sunflower extract, GA3 and salicylic acid increase in yield by 19, 15 and $14 \%$ alternatively almost compared to the treatment of the comparison that has been sprayed with water only. This effect indicates the role of these compounds in improved plant vitality and its activities, which is reflected in the increase and improvement photosynthesis product sink case (number of grains in ear and the weight of the grain). While interference was not significant for the growth regulators and irrigation, while there is no significant interaction between growth regulators and irrigation treatments. An increase in grain yield caused of growth regulators with both skip irrigation and traditional irrigation, spray of sunflower extract has improved, for example, in the skip irrigation yield of grains $(7.49 \mathrm{t} / \mathrm{h})$, including roughly equal to the grain yield in comparison treatments in the traditional irrigation $(7.8 \mathrm{t} / \mathrm{h})$. The increase of maize grain yield as a result of spraying sunflower extract maybe caused by the presence of some phenolic compounds, nutrients and growth regulators of plant which can improve the plant and its parts reproductive, which Maqbool (2010) found that the few concentrations of the sorghum residues extracted when sprayed on maize under drought conditions in the stages of vegetative growth improved the morphological and biological characteristics of the plant. Also Singh et al., (2009) found that the maize spraying with low concentrations of tobacco leaf extract Nicotiana plumbaginifolia improved the effectiveness of the enzyme nitrate reductase in leaves and reduced the antoxidative in plants which exhibit to moisture stress. In another studies pointed (Makkar and Becker, 1996) to spray the plant extract Moringa (Moringa oleifera L.) improved the productivity of some crops such as soybeans (Glycine max. L), sugar cane (Saccharum officinarum. L), maize, sorghum, brown beans ((Phaseolus vulgaris), coffee (coffee Arabica L), pepper (Capsicum annuum L) and onion (Allium cepaL) with a different effect depending on the crop and used items in the study. The GA when externally sprayed might improve the productivity of the plant as a result of increased internal level, that stimulates the growth of the elongation of the cells, which may be affected because of the drought (Rodriguez et al., 2006 and Shao et al., 2008) this is agree with Akter et al., (2014). salicylic acid contributes to the increase flower growth and the number of seeds (Al-Qaisi and Almentfja, 2012) and it has a role in 
improving plant growth and raise photosynthesis efficiency and the accumulation of dry matter (Yazdanpanah et al., 2011) and it has positive effects on increasing the number of fruits and seeds in their natural conditions and the conditions of stress through increased oxygen ratio and reducing abscisic acid in plant (Hayat and Ahmed, 2007).

\section{Biological Yield of plant (t / h)}

Dry matter of plant (biological Yield) are a direct reflection of the demolition and construction process associated with photosynthesis, cell growth and division, which is a key factor in the water of all those operations.

Table.1 Effect of skip irrigation and plant growth regulators on the maize plant high

\begin{tabular}{|c|c|c|c|c|c|}
\hline \multirow[b]{2}{*}{ Irrigation method } & \multicolumn{4}{|c|}{ Plant growth regulator } & \multirow[b]{2}{*}{ Mean } \\
\hline & $\begin{array}{c}\text { sunflower } \\
\text { extract }(5 \%)\end{array}$ & $\begin{array}{c}\text { salicylic acid } \\
(200 \text { p.p.m) }\end{array}$ & $\begin{array}{c}G A 3 \\
(100 \text { p.p.m) }\end{array}$ & $\begin{array}{c}\text { Control } \\
\text { (water only) }\end{array}$ & \\
\hline Skip irrigation & 127.00 & 116.80 & 127.70 & 118.80 & 122.57 \\
\hline $\begin{array}{l}\text { Traditional } \\
\text { irrigation }\end{array}$ & 138.80 & 143.00 & 142.50 & 128.30 & 138.15 \\
\hline L.S.D 0.05 & \multicolumn{4}{|c|}{ N.S } & 12.35 \\
\hline Mean & 132.90 & 129.90 & 135.10 & 123.55 & \\
\hline L.S.D 0.05 & \multicolumn{4}{|c|}{7,54} & \\
\hline
\end{tabular}

Table.2 Effect skip irrigation and plant growth regulators in the number of grain in maize ear

\begin{tabular}{lccccc}
\hline Irrigation method & $\begin{array}{c}\text { Plant growth regulator } \\
\text { sunflower } \\
\text { extract (5\%) }\end{array}$ & $\begin{array}{c}\text { salicylic acid } \\
(\mathbf{2 0 0} \text { p.p.m) }\end{array}$ & $\begin{array}{c}\text { GA3 } \\
(\mathbf{1 0 0} \text { p.p.m) }\end{array}$ & $\begin{array}{c}\text { Control } \\
\text { (water only) }\end{array}$ & Mean \\
\hline $\begin{array}{l}\text { Skip irrigation } \\
\text { Traditional }\end{array}$ & 375.00 & 362.00 & 372.00 & 351.00 & 365.00 \\
$\begin{array}{l}\text { irrigation } \\
\text { L.S.D 0.05 }\end{array}$ & 512.00 & 396.00 & 526.00 & 380.00 & 453.50 \\
$\begin{array}{l}\text { Mean } \\
\text { L.S.D } \mathbf{0 . 0 5}\end{array}$ & 443.50 & 379.00 & & & \\
\end{tabular}

Table.3 Effect skip irrigation and plant growth regulators on weight 500 grains of maize

\begin{tabular}{lccccc}
\hline Irrigation method & $\begin{array}{c}\text { Plant growth regulator } \\
\text { sunflower } \\
\text { extract (5\%) }\end{array}$ & $\begin{array}{c}\text { salicylic acid } \\
(\mathbf{2 0 0} \text { p.p.m) }\end{array}$ & $\begin{array}{c}\text { GA3 } \\
(\mathbf{1 0 0} \text { p.p.m) }\end{array}$ & $\begin{array}{c}\text { Control } \\
\text { (water only) }\end{array}$ & Mean \\
\hline $\begin{array}{l}\text { Skip irrigation } \\
\text { Traditional }\end{array}$ & 157.66 & 141.14 & 157.54 & 139.92 & 149.06 \\
$\begin{array}{l}\text { irrigation } \\
\text { L.S.D 0.05 }\end{array}$ & 150.66 & 157.20 & 138.20 & 152.16 & 149.55 \\
$\begin{array}{l}\text { Mean } \\
\text { L.S.D } \mathbf{0 . 0 5}\end{array}$ & 154.16 & 149.17 & 147.87 & 146.04 & N.S \\
\hline
\end{tabular}


Table.4 Effect skip irrigation and plant growth regulators in grain yield of maize $(\mathrm{t} / \mathrm{h})$

\begin{tabular}{|c|c|c|c|c|c|}
\hline \multirow[b]{2}{*}{ Irrigation method } & \multicolumn{4}{|c|}{ Plant growth regulator } & \multirow[b]{2}{*}{ Mean } \\
\hline & $\begin{array}{c}\text { sunflower } \\
\text { extract }(5 \%)\end{array}$ & $\begin{array}{c}\text { salicylic acid } \\
(200 \text { p.p.m) }\end{array}$ & $\begin{array}{c}G A 3 \\
(100 \text { p.p.m) }\end{array}$ & $\begin{array}{c}\text { Control } \\
\text { (water only) }\end{array}$ & \\
\hline Skip irrigation & 7.48 & 6.94 & 7.02 & 6.08 & 6.88 \\
\hline $\begin{array}{l}\text { Traditional } \\
\text { irrigation }\end{array}$ & 9.61 & 9.12 & 9.29 & 7.8 & 8.95 \\
\hline L.S.D 0.05 & & N. & & & 1.007 \\
\hline $\begin{array}{l}\text { Mean } \\
\text { L.S.D } 0.05\end{array}$ & 8.55 & $\begin{array}{ll}8.03 & \\
& 0.99\end{array}$ & 8.15 & 6.94 & \\
\hline
\end{tabular}

Table.5

Table.5 Effect skip irrigation and plant growth regulators on the dray matter yield of maize (t./h)

\begin{tabular}{|c|c|c|c|c|c|}
\hline \multirow[b]{2}{*}{ Irrigation method } & \multicolumn{4}{|c|}{ Plant growth regulator } & \multirow[b]{2}{*}{ Mean } \\
\hline & $\begin{array}{c}\text { sunflower } \\
\text { extract }(5 \%)\end{array}$ & $\begin{array}{c}\text { salicylic acid } \\
(200 \text { p.p.m) }\end{array}$ & $\begin{array}{c}G A 3 \\
(100 \text { p.p.m) }\end{array}$ & $\begin{array}{c}\text { Control } \\
\text { (water only) }\end{array}$ & \\
\hline Skip irrigation & 18.61 & 17.11 & 18.33 & 17.42 & 17.86 \\
\hline $\begin{array}{l}\text { Traditional } \\
\text { irrigation }\end{array}$ & 21.60 & 20.88 & 20.99 & 17.94 & 20.35 \\
\hline L.S.D 0.05 & & N. & & & N.S \\
\hline $\begin{array}{l}\text { Mean } \\
\text { L.S.D } 0.05\end{array}$ & 20.10 & $\begin{array}{ll}18.99 & \\
& 0.9\end{array}$ & 19.66 & 17.68 & \\
\hline
\end{tabular}

Table.6 Effect skip irrigation and plant growth regulators on harvest index of maize

\begin{tabular}{lccccc}
\hline Irrigation method & $\begin{array}{l}\text { Punflower } \\
\text { extract (5\%) }\end{array}$ & $\begin{array}{c}\text { salicylic acid } \\
\text { (200 p.p.m) }\end{array}$ & $\begin{array}{c}\text { GA3 } \\
(\mathbf{1 0 0} \text { p.p.m) }\end{array}$ & $\begin{array}{c}\text { Control } \\
\text { (water only) }\end{array}$ & Mean \\
\hline $\begin{array}{l}\text { Skip irrigation } \\
\text { Traditional }\end{array}$ & 40.26 & 40.64 & 38.69 & 34.85 & 38.61 \\
$\begin{array}{l}\text { irrigation } \\
\text { L.S.D 0.05 }\end{array}$ & 44.98 & 43.57 & 44.39 & 43.34 & 44.07 \\
$\begin{array}{l}\text { Mean } \\
\text { L.S.D 0.05 }\end{array}$ & 42.62 & \multicolumn{2}{c}{ N.S } & & 3.214 \\
\hline
\end{tabular}

Results in Table 5 shown there is no significant effect of the irrigation treatments on yield of dry matter of the plant, although there is a slight decrease in the treatment of skip irrigation, this may indicate that the biggest effect of the inability of water on parts of the reproductive plant (grain yield in Table 4.) more than the parts vegetative this is due to the failure of the process of fertilization or flowering, which refer to by 
Zinselmeier et al., (1995) and Setter et al., (2001), which will reflect directly on the number of formed grains in ears and this is what appeared in the results shown in Table 2.

Growth regulators affected significantly in the yield of dry matter of the plant. and by ratio of 12,10 and $7 \%$ for treatments spraying remnants of sunflower extract, GA3 and salicylic acid ultimately compared to the treatment comparison, this is due to the role of these compounds to increase growth through increased cell elongation and swollen, which previously indicated by many references as well as the presence of organic and metal compounds essential for growth in these extracts. Interference was not significant between both irrigation treatments and growth regulators, as the influence of independent factors in this status.

\section{Harvest index (HI)}

Harvest index represents the ratio between what is produced from a dry matter (biological yield) to what is produced from the proceeds of grain was highly associated with a system constant capacity (SCC) (Hammoud, 2010). Results shown in table 6 that harvest index has dropped dramatically because of the moisture deficit caused by the lack of irrigation water quantity, it is clear that this decline is due to the decline significantly of grain in skip irrigation treatments (Table 4.) compared influence is non-significant in the yield of dry matter (table 5.) this confirms that the biggest impact of irrigation be on the main components of the grain yield (number of grain or grain weight) more than its effect on plant growth. Growth regulators and overlap with irrigation treatments are not significantly affected the harvest index, which indicates that the effect of growth regulator may be equal in total vegetative and fruiting of the crop, and therefore, the disproportionate increase in the yield of dry matter and grain yield in the treatments, or the comparison will give a convergent value to the harvest index.

Through the search results we can conclude that the use of skip irrigation method and sprayed sunflower extract or GA3 can save $50 \%$ of the amount of irrigation water and improves the productivity quotient grain maize and without significant difference for usual irrigation in natural conditions, this result is considered promising way and lowcost water management and reduce the effects of drought on crop yields.

\section{References}

Abd El-kader, A.M., Saleh, M.M.S., and Ali. M.A. 2006. Effect of soil moisture levels and some antitranspirants on vegetative growth, leaf mineral content, yield and fruit quality of Williams Banana plants. J. Appl. Sci. Res., 2(12): 1248-1255.

Akter, N., M.R. Islam., M. Abdul Karim, and Hossain, T. 2014. Alleviation of Drought Stress in Maize by Exogenous Application of Gibberellic Acid and Cytokinin. J. Crop Sci. Biotech., 17(1): 41-48.

Al-Hussaini, M.K.J. 2013. Improvement of drought tolerance of Vigna radiate L. R. Wilczek by low doses of water extract of Sorghum bicolor L.(Moench). MSc thesis, Biology Department, College of Science, University of Baghdad, Iraq.

Al-Qaisi, W.A. and Almentfji, H.N.H. 2012. the effect of aspirin spray (acetylcholine Salcelik acid) in the growth of plant and holds livestock (Vigna radiate L.) The exhibition of drought stress. Mustansiriya magazine science, 23(8): 67-82.

Alsaadawi, I.S., Sarbout A.K., and AlShamma. L.M. 2011. Allelopathic 
potential of sunflower (Helianthus annuus L.) genotypes on weeds and wheat (Triticumaestivum L.) Crop. (http://www.t andf online. Com/ loi/ gags 20 .

Al-Temimi, A. O. 2010. Effect of interaction of sunflower residues and herbicides on weeds and barley crop. MSc thesis, Biology Department, College of Science, University of Baghdad, Iraq.

Alusi, A.M.A. 2005. Strain response and hybrids of maize under the few and adequacy of nitrogen and water. Doctoral thesis, Collage of Agriculture University of Baghdad.

Anjum, S.A.A., Xie, X.Y., Wang, L.C., Saleem, M.F., Man, C. and Lei, W. 2011. Morphological, physiological and biochemical responses of plant to drought stress. Afric. J. Agric. Biol., 11(4): 437-442.

Blume, A. 2005. Drought resistance, water use efficiency and yield potential-Are they compatible, dissonant, or mutually exclusive? Australian J. Agri. Res., 56: 1159-1168.

Cheema, Z., Farooq, M., and Wahid, A. 2012. Allelopathy: Current Trends and Future Applications. Springer Verlag Publisher, German.

Elmuttalibi, S.A., and Elsahookie, M.M. 1990. Impact of irrigation interval and planting depth on growth and yield of maize:I. Effect on growth of root, steem, and leaves. The Iraqi J. Agric. Sci., 21(2): 96-110.

Elsahookie, M.M., Mahmood, A. and Oraha. F. 2006a. Skip irrigation, variability of tassel and silk, and leaf removal relationship to maize grain yield. The Iraqi J. Agric. Sci., 37(1): 123-128.

Elsahookie, M.M. 2007. Seed growth relations, Field crops department, Faculity of Agriculture, University of Baghdad, Iraq.

Elsahookie, M.M., Oraha, F. and Mahmood. A. 2006b. Role of skip irrigation males: females rows, and location in sunflower performance. The Iraqi J. Agric. Sci., 37(1):117-122.

Foidl, N., Makkar, H.P.S., and Becker K. 2001. The potential of Moringaoleifera for agricultural and industrial uses. In The Miracle Tree: the Multiple Attributes of Moringa, (ed. L. J. Fuglie). pp 45-76.

Fuglie, L.J. 1999. The miracle tree: Moringaoleifera: natural nutrition for the tropics. Church World Service, Dakar, p 68.

Garrity, D.P., and O'Toole, J.C. 1994. Screening rice for drought resistance at the reproductive phase. Field Crops Res., 39: 99-110.

Gupta, S.D. 2011. Reactive oxygen species and antioxidant higher plants. CRC Press. Enfield New Hampshire, USA, $362 \mathrm{p}$

Hammoud, J.A. 2010. Popmaize performance of mutual irrigation and depth of agriculture. Master sThesis.Field crop science, College of agriculture, University of Baghdad, Iraq.

Hayat, R. and Ahmed, A. 2007.Salicylic acid a plant hormone Springer, Dordrecht, Netherlands: $401 \mathrm{p}$.

Hillel, D. 1990. Role of Irrigiation in Agricultural System. In B. A. Stewart, and D. R. Nielson (eds). Irrigation of Agricultural Crops. ASA. CSSA. Monograph, Madison was. P. 5- 29.

Hirt, H., and Shinozaki, C.K. 2004. Plant Responses to Abiotic Stresses. SpringerVerlag, Germany, pp.300.

Humadi, K.B., Al -Hadithi, K. 2000. Use of drainage water as a source of irrigation water for wheat crop. J. water Res., Vol.19 No. 1 p: 1 - 8 .

Ismail, M.A. 2013. Alleviation of salinity stress in white maize (Zea mays L) plant by exogenous application of salicylic acid. American J. Life Sci., 1(6): 248255.

Kole, J. 2011. Wild crop relatives genomic and breeding resource legume crops and forages. Springer, Heidelberg, Berlin: $321 \mathrm{pp}$. 
Lahmood, N. R., Athafah A.H., and Jabbar, F. A. 2014. Allelopathy impact of remnants of the sunflower in the germination and growth of some weed and crops and chemical properties of the soil. Qadisiya J. Agri. Sci., 2(4): 82-96.

Lahmood, N.R. 2012. Allelopathic effect of sorghum (Sorghum bicolor L. Moench) in the associated weed and next crop. Phd. thesis. college of Agriculture, University of Baghdad, Iraq.

Levitt, J. 1980. Responses of Plants to Environmental Stresses. Academic Press, New York. USA.

Makkar, H.P.S., and Becker, K. 1996. Nutritional value and antinutritional components of whole and ethanol extracted Moringaoleifera leaves. Anim Feed Sci. Technol., 63: 211-228.

Maqbool, N. 2010. Exploring the role of sorgaab in improving water stress tolerance in maize at germination and vegetative growth stages. M. Phil Thesis submitted to Department of Botany, University of Agriculture, Faisalabad, Pakistan.

Pessaraki, M. 2007. Hand book of plant and crop physiology 2nd (ed). Marcel Dekker, Basel. Switzeland: 973 p.

Rathinasabapathi, B. 2000. Metabolic engineering for stress tolerance: Installing osmo protectant synthesis pathway. Annals Bot., 86: 709-716.

Saad, T.M., Abdulhussain, F., Al kuaze, G.M. 1985. The most suitable plant density to harvest maize in relation to different level of irrigation, Scientific Research council. Agri. Res. Water Res. J., 4(4): 243-257.

Setter, T.L., Flannigan, B.A., and Melkonian. J. 2001. Loss of kernel set due to water deficit and shade in maize. Shaozhong Alternate furrow irrigation for maize production in an arid area. Agri. Water Manage., 45: 267-274.

Shao, H.B., Chu, L.Y., Shao, M.A., Jaleel, C.A., Mi, H.M., Hong-Mei, M. 2008. Higher plant antioxidants and redox signaling under environmental stresses. Comp. Rend. Biol., 331: 433-441.

Singh, N.B., Singh, D., Singh, A. 2009. Modification of physiological responses of water stressed Zea mays seedlings by leachate of Nicotiana plumbaginifolia. Gen. Appl. Plant Physiol., 35: 51-63.

Steel, R.G. and Torrie, Y.H. 1980. Principles and Procedures of Statistics. Mcgrow. Hill Book Company, Inc. New York.

Yazdanpanah, S., Baghizadeh, A. and Abbasi, F. 2011. The interaction between drought stress and salicylic acid and ascorbic acid on some biochemical characteristics of Saturejahortensis. Afric. J. Agric. Res., 6(4): 798-807.

Zinselmeir, C., Lauer, M.J., Westgate, M.E., and Boyer, J.S. 1995. Reversing drought Induced losses in grain yield sucrose maintains embryo growth in maize. Crop Sci., 35: 1390-1400.

\section{How to cite this article:}

Nabil R. Lahmod, Oda H. Eshkandi and Srra'a. N.M. Al-Eqaili. 2016. Response of Maize to Skip Irrigation and Some of Growth Regulators and Sunflower Extract. Int.J.Curr.Microbiol.App.Sci. 5(9): 249-260. doi: http://dx.doi.org/10.20546/ijcmas.2016.509.028 